\title{
圈 \\ The adoption of 'International Accounting Standard (IAS) 12 Income Taxes': Convergence or divergence with local accounting standards in selected ASEAN countries?
}

\author{
Prem W.S. Yapa ${ }^{1}$, Diane Kraal $^{2}$ and Mahesh Joshi ${ }^{3}$
}

\begin{abstract}
This article concerns inter-disciplinary research on questions about the socio-economic impact of the adoption and convergence of International Financial Reporting Standards (IFRS) with local standards in selected countries. The article approaches the research in two stages. The first stage concerns the findings and analysis relating to the general impact of the IFRS standards on Singapore and Malaysia. Findings reveal that respondents expressed reservations about cited IFRS adoption benefits, including increases of foreign investment and equity cost reductions; and stakeholder confidence has been eroded by the complex harmonising of principles-based 'fair value' requirements. Debate continues on the application of IFRS regarding standards on financial instruments, real estate and agriculture. Our qualitative research methodology of survey uses institutional theory and stakeholder theory for analysis.

The second stage posits further research for IAS12 Income Taxes, given accounting standards are one starting point for tax compliance, and that income taxes form part of financial statements. A test questionnaire was prepared and industry respondents were asked questions on the extent of IAS12's challenges to practitioners in Australia.
\end{abstract}

Keywords: IAS 12, income tax, IFRS, Singapore, Malaysia

JEL Code(s): M40

\footnotetext{
${ }^{1}$ RMIT University, Australia.

${ }^{2}$ Monash Business School, Monash University, Australia

${ }^{3}$ RMIT University, Australia
} 
Yapa, Kraal \& Joshi | The adoption of IAS 12 Income Taxes’: Convergence or divergence

\section{Introduction}

This article concerns one stage of a two-stage qualitative study of the socio-economic impacts of the convergence of International Financial Reporting Standards (IFRS) with local accounting standards on companies in selected Association of South East Asian Nations (ASEAN). The purpose of this article is two-fold. Its first purpose is to present the methodology, findings, analysis and conclusions from the Stage one research, regarding the socio-economic impacts of the convergence of IFRS with local accounting standards on the ASEAN countries of Singapore and Malaysia.

Accounting standards are one starting point for tax compliance and income taxes form part of financial statements, including tax-related note disclosures. Thus, the second purpose is the positing of a future research plan for a specific accounting standard, International Accounting Standard (IAS) 12: Income Taxes and the extent of its convergence and/or divergence from the aims of the International Accounting Standards Board (IASB) for equivalent accounting standards in selected ASEAN countries and Australia. Stage two of the research project (and related preliminary interview findings) is positioned at end of this article, which follows the Stage one findings and conclusion. IAS 12 has been selected based on feedback from respondents in Stage one.

ASEAN countries ${ }^{4}$ are being assisted by major development financing institutions, including the World Bank and the Asian Development Bank, mainly due to the development of global capital markets, the growth of multi-national enterprises and the Asian financial crisis in the mid-1990s (Briston 1990, 195-216). As investors and creditors require up-to-date financial statements and reports, the professional accounting practices of ASEAN countries are being increasingly scrutinised. ASEAN countries are thus under pressure to adopt a uniform set of accounting standards. Convergence of local accounting standards with IFRS is now one of the rising concerns among stakeholders with interests in ASEAN countries (Yapa 2012).

In June 2011 a forum was held in Bali, Indonesia with the theme of, 'Towards One Global Standard: the challenges and opportunities of IFRS adoption in Asia-Oceania Region'. ${ }^{5}$ Delegates from sixteen countries attended the forum to deliver papers and debate issues relating to adoption of IFRS. The presentations and panel discussions highlighted the importance of benchmarking, collegial work among standard setters with other regulatory bodies (including taxing authorities); and professionals to support for IFRS convergence/compliance in the region. Discussions covered the need for tax preparers to understand any differences between the Generally Accepted Accounting Principles (GAAP) and IFRS reporting methods. Thus, along with retraining financial accountants in a new accounting method, organisations will need to ensure other internal preparers, such as tax accountants, understand the different methods.

Access to global capital is problematic without the existence of an institutionalised set of accounting practices. Since 2005 most listed companies located in the European Union, Australia, and New Zealand have prepared their consolidated financial statements in accordance with IFRS (Ali 2005). According to the International Accounting Standards Board (IASB), about 150 countries have adopted IFRS. The year 2012 was when many countries in the Asian region had to formally adopt IFRS, and their regulators and accounting standard setters will face the real challenges (as opposed to theoretical ones) of adoption. The aim of harmonisation of local standards with IFRS is to reduce differences in accounting practices among countries (Bailey and Wild 1998; Banerjee et al. 1998; Burns 2000). Mueller

\footnotetext{
${ }^{4}$ Burma, Brunei Darussalam, Cambodia, Indonesia, Laos, Malaysia, Philippines, Singapore, Thailand and Vietnam.

${ }^{5} 5^{\text {th }}$ IFRS Regional Policy Forum.
} 
(1965, 1967, 1968) has initiated the thesis that accounting is a product of the environment in which it operates. His work has drawn the attention to the need to explain and assess the status of global understanding of IFRS practices and their impact (Carlson 1997; Perera and Baydoun 2007; Perera 1975; Weetman and Gray 1991).

\subsection{Research questions}

Stage one of this qualitative study raised the broad question about the socio-economic impact of the adoption and convergence of IFRS with local accounting standards on companies in two ASEAN countries: Singapore and Malaysia. In order to perform further in-depth analysis on this research question, sub-questions for interviews were posed as follows:

(1) What are the impacts of adoption of IFRS on wider stakeholders and on the socioeconomy in the selected ASEAN countries?

(2) What are the perceived tensions between companies on the potential/adoption of IFRS in the selected ASEAN countries?

(3) What are the ongoing IFRS education and training issues?

The findings for Singapore were that most standards, introduced since 2005, including IAS 12: Income Taxes, have been implemented without much difficulty. IFRS is more established in Singapore compared to Malaysia. However, in Singapore the application of the principles-based 'fair value' requirement of standards has continued to be problematic in the financial services and agricultural sectors. Whilst IFRS education was found to be quite satisfactory, responses were varied as to whether the IFRS regime has been meaningful, including reservations about the reward of lower cost of capital and concerns about loss of competitive position. In Singapore our questions about the IFRS framework setting a momentum for foreign investment revealed a degree of scepticism in the responses.

The move towards IFRS convergence in Malaysia was one of the major plans to respond to Capital Market Master Plan Two (CMP2) that was launched by the Securities Commission at the seventh edition of Invest Malaysia. ${ }^{6}$ By 2012, all approved accounting standards applicable to entities other than private entities were due to converge fully with all IFRS issued by the IASB. In November 2011, the MASB issued a new accounting framework, namely the Malaysian Financial Reporting Standards (MFRS Framework) and approximately one thousand Malaysian public listed companies have been affected since the IFRS convergence in 2012. Malaysia officially adopted IFRS in 2012. There is a clear expectation of positive impacts, such as the attraction of inward investment and resultant increases in standards of living. There is tension amongst financial and tax practitioners, and policy makers with regards to the accounting standards for financial instruments, real estate and agriculture. The 'complexity' of the fair value principles-based approach has impacted confidence, and there are differences for tax. There are concerns about adequate preparatory IFRS training; and problems of low numbers of accountants in Malaysia. There is disquiet about IFRS authorities not taking into account cultural, religious and societal variations around the globe.

The investigation in relation to the research questions and detailed findings are organised in this article as follows: Section 2 explains the methodology and methods. Section 3 discusses the literature review. Section 4 provides the background of IFRS in the selected ASEAN countries considered in this study. Section 5 presents the analysis and discussion. Section 6 contains the Stage one conclusions and Section 7 outlines the directions for further research into IAS 12 Income Taxes.

${ }^{6}$ MASB 11 Exposure Draft 75: IFRS- compliant Financial Reporting Standards, June 2011. 


\section{Methodology}

Stage one uses a qualitative approach to answer key questions about the socio-economic impacts of the convergence of local standards with IFRS. The methodology of survey, using the method of a series of one-to-one interviews is used to gather the primary data; the interview protocol for Stage one is attached as Appendix A. Both perspectives of institutional theory and stakeholder theory are utilised in the analysis. A summary of the interviews conducted in each country is provided in Table 1. It shows that twenty individual interviews were conducted in two countries (9 in Singapore and 11 in Malaysia) with academics, accounting professionals and accounting bodies. In a qualitative study a small sample is acceptable as any generalisations are limited to the data collected.

Table 1

A summary of the interviews conducted in each country

\begin{tabular}{|l|l|l|}
\hline Respondents & Number & Totals \\
& & \\
\hline Singapore & & \\
\hline Big 4 Accounting firms & 2 & \\
\hline Partners/ Directors of Practicing firms & 7 & 9 \\
\hline Malaysia & & \\
\hline Big 4 Accounting firms & 2 & \\
\hline MIA - Representative & 1 & \\
\hline MICPA - Representative & 1 & \\
\hline MASB -Representatives & 2 & \\
\hline Practicing firms & 1 & \\
\hline Accounting Academics & 4 & 11 \\
\hline Total & & 20 \\
\hline
\end{tabular}

Legend: MIA: Malaysian Institute of Accountants; MICPA: Malaysian Institute of Certified Public Accountants; and MASB: Malaysian Accounting Standards Board.

The interview protocol, the same for Singapore and Malaysia has three parts (A, B and C). The copy for Malaysia is attached as Appendix A. The aim of the 'A' interview protocol set was to ascertain interviewee's observations or understanding of the IFRS benefits to wider society. The time and expense devoted to IFRS adoption by each country specific interviewee is implicitly acknowledged. The ' $B$ ' questions were used to gauge views on the technical challenges of the IFRS standards and the wider societal rewards for the national effort in mastering the newly harmonized code of accounting practice. Interview time was insufficient to cover all 41 adopted IFRS standards, and so interviewees were asked to comment on the 'most, and least, important standards.' The enquiry extended to the impact unique cultural attributes on the adoption process; such as Sharia law. The ' $C$ ' questions were used to ascertain the impact of the converged IFRS standards' higher technical demands on the accounting profession-in two societies with low educational resources-and one with adequate resources (Singapore).

A summary of the interviews conducted in each country is provided in Table 1, depicting interviewees by country, professional role (academic, accounting professional or accounting body). Of the practitioners interviewed, some were financial statement preparers. The classes of interviewees for each country are unbalanced, which is a shortcoming of our study, but this was inevitable mostly for cultural reasons. For instance, in Singapore 
interviews were only granted after permission from the national professional body (Institute of Certified Public Accountants of Singapore). In Malaysia 'Big 4' interviews were only granted only after a formal introduction by a mutually known local.

Interviews were conducted between July and September 2011 by a team of three researchers, who visited the two countries and interviewed at the interviewees' nominated site. Interviews were in the English language. The questions were emailed beforehand and the interviews lasted about 30-40 minutes. The majority of the interviews were audio recorded and transcribed. As part of the process some 'follow-up interviews' were conducted with preparers of annual reports where further clarification was requested. These clarifications principally centred on technical challenges of the IFRS standards and adoption issues.

\subsection{Institutional Theory}

An explanation is needed for the phenomena of the willing but costly convergence to IFRS undertaken by the selected ASEAN countries. To address these phenomena the perspective of institutional theory is utilised by this article in the analysis of the convergence/harmonisation issues. Institutional theory can provide explanations about organisational linkage with the environment, social expectations and an organisations internal practices and characteristics (Dillard et al. 2004).

Early organisational theory acknowledged the diversity of organisations, however, others such as DiMaggio and Powell (1983), have since argued that once organisations emerge as a field, the paradox of them becoming increasingly similar is evident. Institutional theory has two main dimensions: isomorphism and decoupling. Isomorphism consists of coercive factors, normative influences, and mimetic factors to explain this paradox of homogenisation. Coercive isomorphism emerges from asymmetric power relationships. Change is required by formal and informal sources, such as government regulation or political pressure groups. Mimetic isomorphism stems from a powerful phase brought on by a major event or incident. In uncertain situations actors, under standard circumstances, copy the legitimatised practices from other actors in the field. Third, normative isomorphism emerges upon the maturity of a certain practices, and is associated with professionalisation, where members of defines their methods of work. Decoupling refers to the creation and maintenance of gaps between formal policies and actual organizational practices (Meyer and Rowan 1977).

Organisations within the selected countries may be seen as an institutionalised field, which is defined as an established social order in relation to a set of rules and standardised practices. The theory reflects on the effects of external expectations of a field and the development of procedures, structures and practices within the organisational field as it seeks to establish its legitimacy. Institutional theorists posit that organisations must be cognisant of, and be responsive to, both their environments and external expectations of groups and organisations (Di Maggio and Powell 1983, 1991; Meyer and Rowan 1977). Clegg (1989) notes that the power of organisational actors must also be understood as an element in organisational change. Thus understanding power and isomorphic pressures can assist by providing social and cultural explanations for the IFRS convergence by organisations in the selected countries. Finally Orru et al. (1991, p. 362-3)use institutional theory to explain how selected East Asian businesses operate according to distinct models; and that institutional and technical components need not be in conflict but can, 'converge harmoniously'. Thus the Orru et al. findings, analysed via institutional theory, might explain how Singapore and Malaysia handled the impacts and tensions of IFRS may not lead to a loss of business efficiency or effectiveness. 


\subsection{Stakeholder Theory}

For both Stage one and Stage two of this research, IAS 12: Income Taxes, stakeholder theory is one of the perspectives used to analyse the findings. A stakeholder may be a consumer, employee, investor, researcher, a community or pressure group, government regulator, or simply an interested individual; and so the term challenges the contention that the corporation's primary responsibility is to deliver profits to shareholders (Friedman 1970; Mitchell et al. 1997). Stakeholder theory assumes that to achieve maximum organisational potential, a "firm" will take the broader stakeholder interest into account (Reich 1988). Freeman's (1984, p. 46)definition of a stakeholder is:

Any group or individual who can affect or is affected by the achievement of the organisation's objectives.

The theory will assist in the analysis and understanding the 'firm'. For example, in this article the firm is the jurisdiction that converges or harmonises its national accounting taxation standard to IFRS. The stakeholders are the professional bodies, educational institutions, practitioners, investors or other entities, which are affected by the change process. The Mitchell et al. (1997) dynamic stakeholder model which proposes that stakeholder importance can be identified by possession of some, or all, of the following attributes: (1) the stakeholder's power to influence the firm; (2) the legitimacy of the stakeholder's relationship with the firm; and (3) the urgency of the stakeholder's claim on the firm. The theory is applied by first considering a stakeholder's power to influence standard setters in their jurisdiction. Then the legitimacy of a stakeholder's relationship with the standard setter to lobby for modifications or change is reviewed; and finally the urgency of a stakeholder's claim is taken into account. The theory requires broad views of the stakeholders to be contrasted with the empirical reality. Thus, when Stage two is undertaken, the intention will be to critically analyse the interview data based on stakeholder theory.

\section{Literature Review}

The literature review is in two parts; the first covering the literature on the development, influences and relevance of IAS (and the associated IFRSs) on non-Western countries; and the second on recent accounting literature in the ASEAN context.

\subsection{Review of the literature on IASs and IFRS}

The IASB has played a leading role in the development of international accounting standards (IAS) and its harmonisation with national standards. As Nobes (1994)points out, harmonisation is the process of increasing the consistency and comparability of accounts in order to remove the barriers to the international movement of capital and exchange of information by reducing the differences in accounting and taxation law. Since the 1973 formation of the IASB, it has grown to 142 member accountancy bodies, which represent over 103 countries. The IASB has promulgated nearly forty IASs on a wide range of financial accounting topics. As indicated by Nobes (1994), common colonial heritage may explain similarities in accounting and disclosure rules. For example, in Malaysia and Singapore the international accounting standards are used as the basis for the development of national accounting standards. In relation to the ramifications of a conversion to IFRS on tax, one report discusses issues associated with product and financial supply chains, intangible transfers, shared service centres and entity rationalization. ${ }^{7}$ Another tax publication discusses

\footnotetext{
7 'Five Ways a Conversion to International Financial Reporting Standards Could Impact a Global Tax Structure'. Viewed 30 April 2012, <Documents settings us_tax_5waysIFRSimpactsglobaltax_091708(2).pdf>.
} 
global tax planning issues related to IFRS that multinationals should immediately consider, including the implications of the transition to IFRS in jurisdictions where multi-nationals operate. $^{8}$ Nevius (2008) poses the question about how IFRS will affect tax practitioners and finds the immediate tax implication is that some items that ordinarily would have been treated as off balance sheet; such as certain types of leases, would now be reflected on balance sheet, giving room for fairer presentation of financial statements.

Empirical research offers insights into the relevance and importance of the IASs in various countries around the world. Many studies have recommended for a customised adoption of IAS to meet a country's local needs (Enthoven 1969; Hassan 1998; Larson 1993; Mirghani 1998; Perera 1985, 1989). Several studies investigated the similarities between the UK, US and IASB standards and found it is mainly due to the dominance of the US and the UK on the IAS Board, and the lack of engagement of developing countries (eg. Hoarau 1995; Hove 1990; Larson and Kenny 1996, 1998). Hove (1990) and Briston (1990) noted the UK and US have strong orientations towards maximising shareholders' wealth, rather than being primarily concerned with the social function of accounting. There is a view that accounting should not be treated as the object of providing useful information to the investors only; accounting also serves the purpose of divergent interested groups. Therefore, the roles and the relevance of the IASs in the developing countries is not clear and still are debatable. Moreover these studies are limited in their investigation of the socio-economic impacts of IFRS adoption in Asian countries.

Some studies conducted on former communist economies have criticised the hegemonial influence of Western accounting standards on IAS (Briston 1990; Hassan 1998; Perera 1989; Points and Cunningham 1998; Samuels 1990; Samuels and Oliga 1982; Wallace and Briston 1993). Inappropriate solutions are suggested to developing countries by developed nations. Thus, Wallace and Briston (1993) indicated the need for using a strategic planning model which capitalises on internal strengths and external opportunities in adopting accounting technologies in developing countries. However, it is argued that given the unique accounting and accountability problems to each developing country, foreign aid agencies should collaborate more closely with recipient countries to ensure that their assistance is delivered only if there are national accounting development plans (Hoarau 1995; Hove 1990; Larson and Kenny 1996, 1998). It is clear that these studies have not contemplated the social and institutional issues emerging from the adoption of IFRS.

Many studies on IAS and indicated the inability to adopt IAS due to various barriers (Larson 1993; Mason 1978; Woolley 1998). Despite these observations, none of these studies have considered the implications of socio- economic factors emerging from IFRS. For Stage one, this article attempts to address this gap identified in the literature. In relation to Stage two, income tax, IFRS lays more emphasis on the balance-sheet disclosures than the profit \& loss account, as the IASB favours fair value accounting over historical accounting. For instance, as a result of the 2007 Global Financial crisis, there was great volatility in losses being reflected in the balance sheet as Deferred Tax Assets.

\subsection{Review of the recent accounting literature in the ASEAN context}

Some of the empirical investigations have criticised the adoption of IASs without harmonisation to national standards in the Southeast Asian countries (Briston 1990; Wallace 1993). Diga (1996) studied the extent of accounting harmonisation among five ASEAN countries: Indonesia, Malaysia, the Philippines, Singapore and Thailand. The results of this

\footnotetext{
8 'Global Tax Implications of International Financial Reporting Standards'. Viewed 30 April 2012< http://www.deloitte.com/view/en US/us/Services/additionalservices/IFRS/df6b55baf1001210VgnVCM100000ba42f00aRCRD.htm>.
} 
study showed that ASEAN countries have achieved a relatively high degree of measurement harmonisation in some areas. By contrast, the study found relatively low harmonisations in accounting for goodwill, income tax and leases, and property, plant and equipment. The reasons found for low levels of harmonisation were the use of malleable and discretionary accounting treatments for similar accounting transactions, and non-disclosure of accounting policies. Diga found that of all the countries, Indonesia and the Philippines showed a significantly low adoption of IASs.

A study by Saudagaran and Diga (1997) examined the similarities and dissimilarities in the regulatory environment of the same five ASEAN countries as in Diga's 1996 work. A key comparative finding was that Indonesia needed to improve its quality of standards and regulations. The authors pointed out those similarities in accounting regulations in most of the countries in the region had led to the dominance of the global paradigm of harmonisation. This study failed to elaborate on the legislation for financial reporting practices among ASEAN countries, that is, company law, securities and exchange law for companies and law regulating auditors.

Some studies have examined various alternative harmonisation options for emerging markets in the ASEAN and colonial influence (Yapa 1999; Yapa 2003, 2005; Yapa et al. 2007). Accordingly, contemporary accounting standards in the ASEAN are heavily drawn from foreign sources, mainly the UK, US and the IASB standards. Perera and Baydoun (2007) studied the influence of the culture on convergence with international accounting standards in Indonesia. The findings of the study indicated that in Indonesia, IFRS are not permitted for domestic listed companies. The possible reason for non-adoption of IFRS has been the accounting environment in Indonesia. For example, they found that IFRS were not permitted for domestic listed companies in Indonesia.

As far as the authors are aware, no study has been conducted to examine the institutional influence, tensions and pressure in relation to professional accounting and adoption of IFRS in the ASEAN region. This article attempts to fill that gap in Stage one. In relation to income tax, there is literature on the IFRS/tax impact on thin capitalisation and debt defeasance, and this part of the literature review will be further developed when Stage two is undertaken (Nethercott 2007; Nethercott and Hanlon 2005; Nethercott and Smith 2006).

\section{Background of IFRS in ASEAN}

The ASEAN region has a population of about 600 million with English as the common language of commerce and diplomacy; a total area of 4.5 million square kilometres; a combined gross domestic product of US\$798.7 billion; GDP per capita of US\$1,467; and a total trade of US\$1,079.4 billion. ${ }^{9}$

The ASEAN Federation of Accountants (AFA) was inaugurated in March 1977. It was established to serve as the umbrella organisation for the national associations of accounting and auditing professionals of the member countries of the ASEAN. The AFA originally had only five member bodies, being the national accountancy bodies of Indonesia, Malaysia, Philippines, Singapore and Thailand. Other members now include the Brunei Institute of Certified Public Accountants (BICPA); the Lao Institute of Certified Public Accountants (LICPA); the Vietnamese Association of Accountants and Auditors (VAA), the Myanmar Accountancy Council: Union of Myanmar (MAC); and Cambodia's, Kampuchea Institute of Certified Public Accountants (KICPAA).

\footnotetext{
${ }^{9}$ ASEAN countries comprise: Burma, Brunei Darussalam, Cambodia, Indonesia, Laos, Malaysia, Philippines, Singapore, Thailand and Vietnam in Fact Sheet on ASEAN 2005.
} 
Choi (1998) noted criticism in the aftermath of the Asian financial crisis included: incomplete financial information, inappropriate accounting standards and inconsistent application of such standards. ASEAN leaders did not prioritise the best options available for disclosure of financial information in the post-crisis period. At the time global forces were already active (such as 'Big 4' accounting firms) and lobbying for the harmonisation of accounting practices across national boundaries. These pressures to adopt IFRS have flowed into the ASEAN region. Wolfensohn, president of the World Bank (1995-2005), summarised disclosure problems: 'The culture in the region has not been one of disclosure; if you go back further it was a culture of a smallish number of wealthy people. ${ }^{10}$ The next sections of the article explain the background of IFRS adoption in the selected ASEAN countries, which utilise some comments from the authors' one-to-one interviews.

\section{-Singapore}

Since 2007, Singapore's Accounting Standards Council (ASC) has prescribed accounting standards for listed companies, co-operative societies and charities. In 2010, the Singapore Stock Exchange had 640 listed companies. ${ }^{11}$ The financial reporting standards issued by the ASC are largely aligned with the IFRS standards. The ASC is responsible for ensuring the reliability, comparison of financial statements of different companies to enhance the credibility and transparency of financial reporting in Singapore. As stated by an interviewee:

Officially Singapore has not adopted $100 \%$ of IFRS, but we are unique for having adopted about $95 \%$ of the standards. Also, full adopting of IFRS has not been a major exercise in Singapore. We did not want it to be a big challenge.

Another interviewee cautioned, 'IFRS 9 Financial Instruments [about classification and measurement] was issued in 2009 and 2010 but is being delayed until after 1 January 2013.' It is interesting to note that the interpretations of some standards have also been delayed. In late 2010 the ASC realised that it needed to address the reduction of the financial reporting burden for Small and Medium Enterprises (SMEs). Thus the Singapore Financial Reporting Standard (SFRS) for Small Entities was adopted without any modifications. Singapore operates a territorial-based taxation system where income-tax is based on income derive from Singapore, foreign sourced income received or deemed to be received (with some specified exceptions), there is no capital gains regime. Generally accounting treatments of tax are used, except where there is a conflict with tax legislation or principles (Chan 2011).

\section{-Malaysia}

The Malaysian Accounting Standard Board (MASB) was established in 1997 to set accounting standards and oversee its governance. These powers were transferred from the local accounting professional bodies: the Malaysian Institute of Certified Public Accountants (MICPA) and the Malaysian Institute of Accountants (MIA). Malaysia is one of the early adopters of global reporting practices, for it has been progressively incorporating the provisions of the international standards into local accounting standards since 2006. The MICPA vice-president and accounting educator interviewees referred to the strong involvement of MASB in the Emerging Economies Group (a sub-committee of the IASB) which aims at enhancing the influence of emerging economies in the development of IFRS.

\footnotetext{
${ }^{10}$ J D Wolfensohn, (1998) 'Address to the Overseas development Council Conference on Asia's coming explosion', Speech delivered at the Overseas Development Council Conference, Washington DC, 19 March 1998. Viewed 1 May, <http://elib.unirazak.edu.my/htm/wbankspeech1.htm >.

${ }^{11}$ Singapore Exchange Ltd, 2011. Viewed 9 October 2011, <http://www.sgx.com/wps/portal/sgxweb/home/>.
} 
During the period 2006 to 2009, the MASB and the IASB sorted out many divergent framework issues, which led to some harmonised standards being operative in 2009; for instance, FRS 8 Operating Segments. A 'Big 4' interviewee noted however, that by 2010 a number of Malaysian accountants 'panicked about the big bang' adoption for that year, including the 'difficult' operative standards IAS 39 Financial Instruments: Recognition and Measurement and IFRS 7 Financial Instruments: Disclosures. The year 2011 was lighter for listed entities in terms of new standards, for Malaysia adopted the 'simpler' IFRS 3 Business Combinations. When the balance of IFRS harmonised standards are adopted in 2012, one year of comparison will be required, so in effect the date of transition for many has been from 1 January 2011. Some interviewees have optimistically stated, 'by 1 January 2012 there will only be minor GAAP differences between Malaysia's FRS and IFRS.' According to one 'Big 4' interviewee, the current perception of a 'large impact' on adoption of IFRS is in fact, 'not significant.' Malaysia has adopted IAS 12 Income Taxes, which superseded the MASB approved Accounting Standard IAS 12, Accounting for Taxes on Income. ${ }^{12}$

\section{Analysis and discussion}

This section, in three parts, presents the Stage one analysis (using the institutional theory and stakeholder theory) the data drawn from the one-to one interviews in Singapore and Malaysia on the topics of the impact of IFRS on wider stakeholders; perceived tensions on the adoption of IFRS; and ongoing IFRS education and training issues.

\subsection{Analysis of impacts of IFRS on wider stakeholders -Singapore}

Stakeholders in Singapore interested in financial performance of listed companies include: shareholders, debt holders, financial institutions, audit committees, external auditors, investors, employees, and labour unions; all have been impacted differently by IFRS. For example, the employees of some companies have been advised to redesign their employee stock options plans or risk associated losses under the IFRS environment. One 'Big 4' interviewee-stakeholder observed:

I think IFRS adoption in Singapore is important to improve the comparability of financial statements between companies that operate in Singapore and other parts of the world... The mandatory adoption of IFRS in Singapore is based on the strength of legal enforcement in our country.

In the managerial branch of stakeholder theory it is expected that the organisation (in this case the jurisdiction) will meet the information demands of particular stakeholder groups if they are important to the organisation achieving its goals. As Gray et al. (1996, p.46) state, information (including financial accounting information and information about the organisation's social performance) is a major element that can be employed by the organisation to manage (or manipulate) the stakeholder in order to gain their support and approval, or to distract their opposition and disapproval.

Another interviewee from a practicing firm commented that from the early stages Singapore has been very positive towards the adoption of IFRS. Firstly, the Singapore Institute of CPAs has been active in working towards the convergence with IFRS framework. This suggests a tendency towards institutional isomorphism in the convergence process. Secondly, the government's Accounting Standards Council has been steering the harmonisation exercise and expects a momentum in the business development, international investments, financial transparency and good governance within and around neighbouring

\footnotetext{
${ }^{12}$ For MASB, see< http://www.masb.org.my/index.php?option=com content\&view=article\&id=1111:masb25income-taxes-pg1\&catid=7:masb-for-private>. Viewed at 30 April 2012.
} 
Southeast Asia. The two examples cited indicate the IFRS impact on both the profession and the state, which have contributed to the adoption of IFRS: The involvement of the state and the accounting profession clearly indicates evidence of coercive isomorphism, which emerges from asymmetric power relationships.

\section{-Malaysia}

Malaysian interviewees noted the problematic impact of the 'fair value' principles approach in FRS 139 Financial Instruments: Recognition and Measurement. They predicted that auditors, in particular, will find fair value difficult to assess. More professional education and additional examples in the Malaysian FRS standards are required, it was claimed.

An academic interviewee noted that IFRS has no impact on access to financial information because listed companies in Malaysia already have their accounts on the public websites. SMEs by contrast (about 300,000) are not required to be IFRS compliant, or publically disclose financial information. A professional body interviewee stated that the promotion of IFRS has been driven by the IASB, but to keep the IFRS impact in perspective, in Malaysia there are only around 1,000 listed companies (most are family run) and a smaller number of financial institutions.

Positive IFRS impacts on the wider group of stakeholders (such as shareholders, trade unions and employees) in Malaysia include an increased attraction of incoming capital, because of comparability of results across jurisdictions; Malaysians recognise the convergence/harmonisation process. Entities with outward investment, such as the many Malaysian construction companies operating in Dubai, will also benefit. Some interviewee's anticipate (and expect) that listed entity costs of compliance and finance will be lower. It should be noted here that if the stakeholder group is not considered to be 'powerful' then their information demands might be ignored. As Deegan (2011) argues, these expectations and power relativities can change across time, organisations must continually adapt their operating and reporting behaviours. Other positive IFRS impacts are seen to be higher inward investment, which will translate to increased standards of living for Malaysians; and more job opportunities for accountants in Malaysia and overseas.

One negative perception is ambivalence as to whether IFRS will fix the current lack of transparency in Malaysian financial reporting. One academic interviewee stated that investors rely on analyst reports rather than comparing financial reports at source (which is similar a Singapore interviewee's observation). Generally, academic interviewees were concerned about IFRS impact; they emphasised the need for a clear implementation plan and more stakeholder participation. Overall, there are pressures emerging in Malaysia from external parties, who are questioning the complexity and usefulness of IFRS; it could suggest coercive isomorphism exists in the adoption of IFRS in Malaysia, as found in Singapore. In both counties the professional bodies were required by the state authorities to adopt IASs, which shows both Singapore and Malaysia had a similar coercive isomorphism in the accounting environment.

\subsection{Perceived tensions on the adoption of IFRS -Singapore}

Singapore interviewees were asked about the perceived tensions emerging from the adoption of IFRS. For instance, complexities in understanding the interpretations of some standards were repeatedly mentioned, despite the fact that IFRS has been progressively adopted since 2005. The most contentious aspect of IFRS is the use of fair value, as it requires increasing professional judgement and subjectivity. An example of the subjectivity required can be found in IAS 39 Financial Instruments: Recognition and Measurement. It includes a section on 'How to Determine Fair Value', which states: 
Yapa, Kraal \& Joshi | The adoption of IAS 12 Income Taxes': Convergence or divergence

The best estimate of fair value at initial recognition of a financial instrument that is not quoted in an active market is the transaction price, unless the fair value of the instrument is evidenced by other observable market transactions, or is based on a valuation technique with variables that include only data from observable markets.

Singapore's banking sector contains tensions mainly due to operations of overseas branches. For instance, the 'effective interest rate', which is the rate that discounts estimated future cash payments or receipts through the expected life of a financial instrument. As noted by an interviewee 'an effective interest rate' impacts on customer statements and 'back-end' accounting. The benefits IFRS was supposed to provide a lower cost of capital, but due to difficulties, such as fair value and effective interest rate, 'some organisations have lost their competitive position.'

The agricultural sector in Singapore also has tensions as there is no adequate statistical data available for comparative purposes. ${ }^{13}$ As confirmed by an interviewee:

The book value is the best for it is reliable. The fair value is subject to professional judgement. It works extremely well in the market if you have observable data on markets. For example, IAS 41 Agriculture [requires fair value] but there is no observable data available in Singapore.

IAS 41 Agriculture requires measurement of biological assets at fair value. As one interviewee noted, 'the standard presumes availability of fair values for various biological assets.' He elaborated stating, 'in our context, fair values of biological assets, such as crops, animals etc. are not readily available; and where available, their reliability is doubtful'. Interviewees consistently mentioned that it is important to grasp the technical issues of fair value. As explained by a practitioner interviewee:

Accounting professionals have to learn new methods of valuation used in implementation for IFRS. There are many methods in IFRS, especially in asset valuation which have not been used before. I think this is a big change. Audit firms now have to think about expertise in valuation to sort out valuation exercises associated with fair value.

IAS 11 Construction Contracts standard, which was issued by the ASC in January 2009, has created tensions between real estate developers and the Urban Redevelopment Authority of Singapore. The standard requires that revenue is recognised using the percentage of completion (POC) method. One interviewee explained that under the new standard an entity (developer) may have only partially completed a development, but can still on-sell the property. Ambiguity arises over the degree of ownership benefits and effective control over the property.

Similarly, concerns were expressed about IFRS 2 Share-Based Payments where proper classification of share-based payments is unclear especially with joint ventures. As indicated by an a 'Big 4' interviewee, fair value in the income statement is not always possible because, 'what is the right answer? It needs a lot of professional judgement.'

Interviewees were consistently critical of the continuously changing nature of IFRS standards. They were also critical of the lead time for financial disclosure, which results in untimely financial statements for potential investors. Investors are therefore relying on other information sources, such as financial analysts' reports. Some major questions were raised by interviewees about the actual usefulness of IFRS standards to potential investors. Reduction of the cost of capital was supposed to be one of the benefits behind the adoption of IFRS, but interviewees had reservations about whether there is a lower cost of capital for business in

${ }^{13}$ The fair value implicitly assumes that the financial markets are efficient. 
Singapore. Despite all these perceived tensions about the adoption of international standards, Singapore continues on its IFRS convergence. Institutional theory explains that in times of uncertainty or major change (such as IFRS) actors copy or mimic the legitimatised practices from other actors in the field. That_organisations in Singapore persist with the convergence of IFRS suggests that there is a significant degree of mimetic behavior in corporates.

\section{-Malaysia}

Interviewees in Malaysia were probed about tensions arising from IFRS adoption, noting that the largest industries in Malaysia are banking and finance, plantations and property development. First, a key tension exists with FRS 141 Agriculture for most interviewees, particularly the MICPA ${ }^{14}$ representative, who saw the agriculture standard as a challenge, including and issues in relation to fair value, the need to use valuation models, and market volatility. Reservations with regards to fair value are exacerbated perhaps by the cultural preference that is less inclined toward argument and discussion. Given the size of Malaysia's agriculture industry (palm oil, fisheries, timber) interviewees claim that the country needs more objective valuation models for biological assets.

Second, FRS 15 Construction of Real Estate was also reported as being contentious. FRS 15 recognises profits only on sale (the current standard prescribes the percentage completion method). Until agreement on a modification is met, the property development and plantation sectors are likely to be exempt from the contentious FRS 141 Agriculture and FRS 15 Construction of Real Estate as at 1 January 2012.

Third, one interviewee (from a small consultancy) claimed that the Global Financial Crisis (GFC) delayed the introduction of FRS 139 Financial Instruments: Recognition and Measurement until 2010, because of likely impairments to assets and its principles (rather than rules) format. Other interviewees disagreed, stating that the GFC in 2008 did not affect the Malaysia's IFRS harmonisation.

Fourth, provisions of IFRS apply, unless there is a clear prohibition under Shari'a law, which one interviewee (from MASB ${ }^{15}$ ) said, 'in the Malaysian experience is very rare'. Interviewees observed that the Malaysian Government wants to promote Islamic financing, with the most discussed issue being the Shari'a law prohibition of interest payments. Most interviewees saw no tension in this requirement, 'as interest is just a terminology issue.' A MICPA interviewee and two accounting academics (who have been associated with MASB $^{16}$ ) claimed that IFRS financial reporting requirements do not generally conflict with Shari'a law, 'as there is always a profit element, which will give the same rate of return compared to interest.' In other words, there is compensation for the time value of money. A contract may not mention interest in a Shari'a transaction, but the accounting entries will treat profit like interest. One potential tension issue is leasing, because under Shari'a law one is not allowed to discount.

Finally, SMEs in Malaysia are currently exempt from IFRS compliance. They use another reporting framework called the Private Entity Reporting Standard (PERS) which may replace IFRS and could be a future source of tension because of costs, such as the need for qualified staff.

Institutional theory posits that organisations in an institutional field tend to adopt similar social structures and patterns of behaviour. This explains the pressure on practices to change towards an Islamic framework; it could even produce a decoupling between the IFRS standard and actual practice as seen in IAS 39 Financial Instruments. According to this

\footnotetext{
${ }^{14}$ Malaysian Institute of Certified Public Accountants.

${ }^{15}$ Malaysian Accounting Standards Board.

${ }^{16}$ MASB: Malaysian Accounting Standards Board.
} 
Yapa, Kraal \& Joshi | The adoption of IAS 12 Income Taxes’: Convergence or divergence

standard, effective interest rate has to be applied, but under Shari'a law interest or 'riba' is prohibited.

\subsection{Ongoing IFRS education and training issues -Singapore}

Singapore interviewees agreed that IFRS education and training in finance and tax is quite satisfactory in the three major local universities (National University of Singapore, Nanyang Technological University and Singapore Management University). The 'Big 4' and other firms have their own in-house training programs to educate their staff. Most interviewees mentioned that financial newspapers are widely available and financial information is updated on a daily basis for the general public. The Business Times is an on-line newspaper and the most widely read business newspaper. In addition, local TV stations run daily financial programs and were rated as 'high'. Stock market information from the Singapore Stock Exchange is displayed in all the major business centres.

The Institute of Certified Public Accountants of Singapore (ICPAS) publishes its CPA Singapore journal with regular updates on IFRS standards, including tax. The ICPAS website is updated with the IFRS related information. Regular IFRS seminars and workshops are being conducted by the ICPAS. One of the interviewees of Singapore, a visiting auditing lecturer to a Singapore university, was positive about the curriculum IFRS updates and associated work integrated learning programs. His view was that by employing practitioners as visiting lecturers to university business programs, students would be enriched with latest developments in the field. He said, 'students would gain a wider awareness about the practical realities of the profession and consequently they would be able to contemplate practical solutions to address complicated issues prevailing in business.'

Overall, there is satisfaction with IFRS education. This satisfaction could be linked with normative isomorphism, where professionals in various disciplines, in association with the collective efforts of members of the professional field, are able to define the conditions and methods of their work training and attitudes. This establishes a suitable cognitive base and legitimacy for their professional field to address future challenges in the profession.

\section{-Malaysia}

Industry claims that public university business graduates are not, 'trained ready for work' and the standard is not high enough; consequently there is a need for further technical training for graduates. For SMEs that tend to rely on non-qualified staff, there is a big gap compared to those who are qualified. There is a need to explore a 'train the trainers' system for IFRS.

Viewpoints of academics and the MICPA interviewee differed on Malaysian graduates' knowledge of international accounting standards. The MICPA official argued that industry requires re-training of business graduates and advised that these graduates only have rudimentary knowledge/skills. However, academics were confident about standards of business education in Malaysia and readiness for employment.

The 'Big 4' have strong in-house professional training programs for IFRS. For accountants in industry there is IFRS training given by the Malaysian Institute of Accountants (MIA), MICPA, the Association of Chartered Certified Accountants (ACCA, UK) and CPA Australia. The MICPA official spoke very positively about training facilities and availability of IFRS literature on MICPA/MIA/MASB websites. The corporate sector is supported by government as companies can apply for training funding under the Skim Bantuan Latihan (SBL) scheme. Academic interviewees saw IFRS continuing education as the domain of the professional bodies. However, they also emphasised that business education in Malaysia is standardised by the Malaysian Qualifications Authority, which ensures benchmarks for academic quality are met by Malaysian universities. 
When interviewees in Malaysia were queried about primary sources of financial information, most stated that Malaysia's Age Financial Daily was their most widely read local newspaper for financial news; including developments in IFRS. The internet is the next source of financial news. The New Straits Times newspaper and television financial news were rated as low quality as both are government controlled. On-line newspapers have been vocal, for instance, criticisms of the proposed goods and services tax. ${ }^{17}$

In relation to IFRS journal articles, the MIA does publish some articles in its journal Accountants Today, 'but it is not doing enough'. Many interviewees did not notice IFRS related materials on the MIA web, although members can go to the International Federation of Accountants (IFAC) website for materials on IFRS. Interviewees acknowledged IFRS surveys conducted by professional bodies; one respondent mentioned the MIA random reviews of listed company financial statements for IFRS compliance. There was also an MIA/IASB survey on the potential for FRS to be applied to Malaysian SMEs.

In Malaysia there is a high turnover of accounting staff in the 'Big 4', which one interviewee claimed to be about '30\%-40\% per annum.' Despite staff leaving to go into industry, there is a shortage of accountants in Malaysia. It was stated that the Enron case gave accountants a 'bad name' and parents are not encouraging accounting as a vocation; they would rather see their children in the IT industry where the working conditions are better. There is also the 'brain drain' of accountants to higher salaried locations, such as Singapore.

The phenomenon of the qualification standardisation process can be described as normative isomorphism, whereby through the collective efforts of a profession, qualifications are aligned for the market place in an attempt to legitimise the field. However, this quest for legitimisation could be undermined by qualified staff shortages and might need to be 'repaired' (Suchman, 1995) to retain legitimacy.

\section{Conclusion for stage one}

This article seeks to contribute to the limited literature relating to impacts of IFRS in Singapore and Malaysia and their socio-economic impact onwider stakeholders, perceived tensions on the adoption of IFRS; and IFRS knowledge and accounting education. Interviewees in Singapore claim that most accounting standards have been implemented without much difficulty, the result of good co-operation between the state and the profession. The application of 'fair value' has been problematic, mainly due to the requirement for greater professional judgement require for the financial instruments and agriculture standards. In all, interviewees were varied in their responses as to whether the adoption of IFRS regime over the last six years has been meaningful, including reservations about the reward of lower cost of capital and concerns about loss of competitive position. The rhetoric in Singapore about the IFRS framework setting a momentum for foreign investments has revealed a degree of scepticism.

As Malaysia has officially adopted IFRS in 2012, it was found respondents agreed that coercive forces from stakeholders especially regulatory forces have influenced their implement IFRS in Malaysia. Many interviews expect to see positive impacts across the community, such as inward investment attraction and resultant increases in standards of living. The adoption of the IFRS framework has created some tension amongst practitioners and policy makers with regards to the accounting standards for financial instruments, real estate and agriculture. The latter two are likely to have a delayed implementation because of fair value concerns, whilst the 'complexity' of the principles approach has impacted confidence in the financial instruments standard. There are concerns about adequate

\footnotetext{
${ }^{17}$ E.g. Chan, 'Workers 100\% against GST', Malaysiakini (online). Viewed 26 April 2010, < http://www.malaysiakini.com/news/130236>.
} 
Yapa, Kraal \& Joshi | The adoption of IAS 12 Income Taxes': Convergence or divergence

preparatory IFRS training; and problems of low numbers of accountants in Malaysia. Some interviewees mentioned that IFRS is being introduced by authorities without taking into account cultural, religious and societal variations around the globe.

While Stage one provides some useful insights about the adoption of IFRS in Singapore, and Malaysia, more extensive research is needed particularly examining the effectiveness of IFRS in ASEAN. Nonetheless, the findings to date and theoretical perspectives may be of interest to institutional and stakeholder theorists, and accounting researchers.

\section{Future research: IAS 12 Income Taxes}

Future research for this project will focus on specific accounting standards, and for Stage two it is International Accounting Standard (IAS) 12: Income Taxes. The equivalent Australian standard is AASB 112: Income Taxes. A qualitative research framework will be used for considering the extent of the IAS 12 convergence or divergence from the aims of the IASB for equivalent accounting standards in selected ASEAN countries and Australia. The methodology of survey will be used with the methods of a questionnaire and a series of oneto-one interviews (as for Stage one). Also, any submissions by the selected countries' accounting bodies to the IASB on convergence with IAS 12: Income Taxes will be analysed.

The questionnaire will target both in-house tax professionals as well as external advisors, with a cross-section of both tax accountants and lawyers in Australia, Singapore (extended sample) and Malaysia (extended sample). The questionnaire will attempt to elicit responses on socio-economic impacts of the adoption and convergence of IAS 12: Income Taxes and include specific aspects of the standard, such as treatment of carry-forward losses. The one-to-one interviews will include a cross-section of professionals in Australia, Singapore (extended sample) and Malaysia (extended sample) but exclude those who responded to the questionnaire. The interview protocol for Stage two is attached as Appendix A (as used in Stage one) and is extended by new tax-specific questions in Appendix B. To test the Appendix B interview protocol, in late 2011 we undertook a small sample of four interviews in Australia comprising: an accounting standard technical advisor from a professional body; an audit partner with a $2^{\text {nd }}$ tier accounting firm; a Chief Financial Officer of an ASX listed mining company and a tax partner with a $2^{\text {nd }}$ tier accounting firm. The test sample findings (without analysis given the sample size) follow.

\section{-Test sample responses about AASB $112^{18}$}

On question one, relating to the impact on judgement required by practitioners in relation to Fair Value valuation of an asset and the comparison to its tax base, the professional body advisor saw the financial accountant's role as separate from the tax accountant's role; in other words 'quite well demarcated.' The audit partner saw judgement issues only where there was no observable market to support the carrying amount of an asset. In this scenario 'valuation models and fairly aggressive assumptions are relied upon.' Quite often there are last minute adjustments to asset values. The area of least agreement 'is impairment of assets', but in the end the auditors have the final say on the matter of valuation; the tax partner agreed. The mining exploration Chief Financial Officer has no assets of great value in his organisation, just the problem of tax losses, but with no recognition of Deferred Tax Assets (DTA) on the

\footnotetext{
${ }^{18}$ Appendix B: Interview Protocol has been used.
} 
balance sheet. This is because there future taxable profits (against which to offset the losses) cannot be ascertained with any certainty.

On question two, relating to the impact on judgement required by practitioners in relation to review/discount approaches to tax losses during the GFC year of 2008/09, the professional body advisor regarded some industries, such as new mining, being affected adversely by negative annual reviews of tax losses and the resultant reduced value of a Deferred Tax Asset (DTA). He saw revaluation of DTAs as the area where an auditor will have the final decision; the tax partner agreed. The audit partner acknowledged tension with his clients when it was necessary to decrease the value of a DTA (as did the professional body advisor and mining CFO) and felt there 'should be a bit more guidance' by the IASB or Australian Accounting Standards Board (AASB).

On question three, which concerned the difficulties encountered by in-house accountants' in determining the tax base of assets/liabilities, the professional body advisor said the reason was 'lack of knowledge of tax law.' The mining Chief Financial Officer saw two specialist accounting areas in a larger organisation: financial and tax. Those in smaller enterprises relied on their auditors. He said, 'the tax effect accounting is what you focus on, the rest is just window dressing.' The tax partner saw tax base as reasonably straight forward, 'provided that proper tax cost base records are maintained.'

On question four, about recent changes in Australian tax law that might have made calculations under AASB 112: Income Taxes more difficult, the tax partner said that the, 'adoption of the balance sheet approach and the removal of the profit and loss approach was significant. I believe that most accountants still do not understand the balance sheet approach very well and a number of errors are made.' The other three interviewees declined to answer, in what was seen as a specialist area.

For the last question, five, about personal views of the benefit to wider stakeholders (shareholders, community etc.) of AASB 112: Income Taxes, the professional body advisor said that even without considering the tax standard, 'many stakeholders can barely understand and annual report.' The audit partner said, 'many people do not like the AASB 112 standard...as it runs contrary to the conceptual framework of accounting.' The framework requires that a transaction has occurred and is accounted for. In many cases DTAs are 'not connected to any past event', but rather a future event. AASB 112 requires repeated explanation to management. The mining Chief Financial Officer said, 'I think the standard is just confusing.' IFRS harmonised standards are important for large multi-nationals for comparability, but for the rest of industry 'they are marginal at best.' The tax partner stated:

Tax expense is quite often the single largest expense of a company. Therefore, it is essential that it is correctly provisioned otherwise the accounts will be materially misstated. The balance sheet approach has the advantage that you are required to prove your balance and the movement from year to year. This reduces the errors in the accounts. Under the old standard you did not have to reconcile movements and tax expense was used [incorrectly] as a balancing item. Whilst, the current standard [AASB 112] is more difficult to apply in practice, it is a lot more transparent.'

The tax partner was the most comfortable in answering all the questions posed above. This does not bode well for an accounting standard designed to be used internationally, and be meaningful to stakeholders. In preparation for Stage two of the research project, a balanced selection of tax professionals and non-tax professionals for survey will be important so as not to skew the results. Stage two will aim practical information to accounting regulators, standard setters, external auditors and tax authorities in Singapore, Malaysia and Australia. 
Yapa, Kraal \& Joshi | The adoption of IAS 12 Income Taxes’: Convergence or divergence

\section{References}

Ali, M. (2005), 'A synthesis of empirical research on international accounting harmonisation and compliance with international financial reporting standards', Journal of Accounting Literature, vol. 24, pp. 1-52.

Bailey, G. and Wild K. (1998), International Accounting Standards: A guide to preparing accounts, Accountancy Books.

Banerjee, B., Martens S. and McEnroe J. (1998), 'Accounting Standard-Setting: A comparison of India and the United States, Supplement 1', Advances in International Accounting, pp. 239-251.

Briston, R. (1990), 'Accounting in developing countries: Indonesia and The Solomon Islands as case studies for regional co-operation', in Research in Third World Accounting.

Burns, J. (2000), 'The Dynamics of Accounting Change: Inter-play between new practices, routines, institutions, power and politic', Accounting, Auditing and Accountability Journal, vol. 13, no. 5, pp. 566-596. http://dx.doi.org/10.1108/09513570010353710

Carlson, P. (1997), 'Advancing the harmonisation of international accounting standards: exploring an alternative path', The International Journal of Accounting, vol. 32, no. 3, pp. 357-378. http://dx.doi.org/10.1016/S0020-7063(97)90016-9

Chan, H. (2011), "“Tax Legislation in Asia." In papaers presented to the 5th IFRS Regional Policy Forum. Bali, Indonesia, June.

Choi, F. (1998), 'Financial Reporting Dimensions of Asia’s Financial Crisis', Indian Accounting Review, vol. 2, no. 2, pp. 1-11.

Clegg, S. (1989), Frameworks of Power, Sage Publications. http://dx.doi.org/10.4135/9781446279267

Deegan, C. (2011), Financial Accounting Theory, 3rd Edition, McGraw-Hill.

Di Maggio, P. J. and Powell W. W. (1983), 'The Iron Cage Revisited: Institutional Isomorphism and Collective Rationality in Organizational Fields', American Sociological Review, vol. 48, no. 2, pp. 147-160. http://dx.doi.org/10.2307/2095101

Di Maggio, P. J. and Powell W. W. (1991), 'Introduction', (eds.) Walter W Powell and Paul J Di Maggio, in The New Institutionalism in Organizational Analysis, The University of Chicago Press, pp 1-38.

Diga, J. (1996), "The Feasibility and Desirability of Pursuing Accounting Harmonisation in Five ASEAN Countries: A study of corporate financial reporting in Indonesia, Malaysia, the Philippines, Singapore and Thailand." PhD Thesis, Australian National University.

Dillard, J. F., Rigsby J. T. and Goodman C. (2004), 'The Making and Remaking of Organization Context: Duality and the institutionalization process', Accounting, Auditing \& Accountability Journal, vol. 17, no. 4, pp. 506-542. http://dx.doi.org/10.1108/09513570410554542

Enthoven, A. (1969), 'Accountancy and Economic Development', Finance and Development, vol. 6, no. 2, pp. 16-23.

Freeman, R. (1984), Strategic Management: A Stakeholder Approach, Pitman.

Friedman, M. (1970), "The Social Responsibility of Business is to Increase its Profits," New York Times Magazine, 13 September.

Gray, R., Owen D. and Adams C. (1996), Accounting and Accountability: Changes and challenges in corporate social and environmental reporting, Prentice Hall.

Hassan, N. (1998), 'The Impact of Socio-Economic and Political Environment on Accounting System Preferences in Developing Economies. Supplement 1', Advances in International Accounting, pp. 43-88. 
Hoarau, C. (1995), 'International accounting harmonisation: American hegemony or mutual recognition with benchmarks?', The European Accounting Review, vol. 4, no. 2, pp. 217-233. http://dx.doi.org/10.1080/09638189500000012

Hove, M. (1990), 'The Anglo-American Influence on International Accounting Standards: The case of the disclosure standards of the International Accounting Standards Committee', Research in Third World Accounting, vol. 1, pp. 55-66.

Larson, R. (1993), 'International Accounting Standards and Economic Growth: An empirical investigation of their relationship in Africa', Research in Third World Accounting, vol. 2, pp. 27-43.

Larson, R. and Kenny S. (1996), 'Accounting Standard-Setting Strategies and Theories of Economic Development: Implications for the adoption of international accounting standards', Advances in International Accounting, vol. 9, pp. 1-20.

Larson, R. and Kenny S. (1998), 'Developing Countries' Involvement in the IASC's Standard-Setting Process. Supplement 1', Advances in International Accounting, pp. 17-41.

Mason, J. (1978), "Accounting Standard Setting in Developing Countries." Proceedings in the South East Asia University Teachers’ Association Conference, Jakarta Universitas, Indonesia.

Meyer, J. and Rowan B. (1977), 'Institutional Organizations: formal structure as myth and ceremony', American Journal of Sociology, pp. 340-363. http://dx.doi.org/10.1086/226550

Mirghani, M. (1998), 'The Development of Accounting Standards in the Kingdom of Saudi Arabia: An international accounting standards perspective. Supplement 1 ', Advances in International Accounting, pp. 195-206.

Mitchell, R., Agle B. and Wood D. (1997), 'Toward a Theory of Stakeholder Identification and Salience: Defining the Principle of Who and What Really Counts ', Academy of Management Review, vol. 22, no. 4, pp. 853-886.

Mueller, G. (1965), 'Whys and Hows of International Accounting', The Accounting Review, vol. 40, no. 2, pp. 386-394.

Mueller, G. (1967), International Accounting, Macmillan.

Mueller, G. (1968), 'Accounting Principles generally Accepted in the United States Versus those Generally Accepted Elsewhere', The International Journal of Accounting, vol. Spring, pp. 91-103.

Nethercott, L. (2007), 'The Consequences of IFRS on Thin Capitalisation’ (2007)', Taxation Today, vol. October, no. 1, pp. 20-25.

Nethercott, L. and Hanlon D. (2005), 'The Increasing Divergence between Accounting Practice and Taxation Law: The Case of In Substance Debt Defeasance', Australian Tax Forum, vol. 20, pp. 101-120.

Nethercott, L. and Smith A. (2006), 'Thin Capitalisation Rules and the Introduction of International Financial Reporting Standards: A New Zealand Perspective', New Zealand Journal of Taxation Law and Policy, vol. 12, no. 1, pp. 61-77.

Nevius, A. (2008), 'How Will IFRS Affect Tax Practitioners?', Journal of Accountancy, vol. 205, no. 6, pp. 100-120. Veiwed at 30 April 2012, < http://www.journalofaccountancy.com/Issues/2008/Jun/HowWillIFRSAffectTaxPractiti oners.htm>.

Nobes, C. (1994), A Study of the International Accounting Standards Committee, Albert Robins and Co Ltd.

Orru, M., Biggart N. and Hamilton G. (1991), 'Organizational Isomorphism in East Asia ', (eds.) Walter W Powell and Paul J Di Maggio, in The New Institutionalism in Organizational Analysis, The University of Chicago Press. 
Yapa, Kraal \& Joshi | The adoption of IAS 12 Income Taxes': Convergence or divergence

Perera, H. and Baydoun N. (2007), 'Convergence with International Financial Reporting Standards: the case of Indonesia', Advances in International Accounting, vol. 20, pp. 201-224. http://dx.doi.org/10.1016/S0897-3660(07)20007-8

Perera, M. (1975), 'Accounting and its environment in Sri Lanka', ABACUS, pp. 86-96. http://dx.doi.org/10.1111/j.1467-6281.1975.tb00045.x

Perera, M. (1985), "The Relevance of International Accounting Standards to Developing Countries." Working Paper No. 85-8, School of Financial Studies, University of Glasgow, Scotland, UK.

Perera, M. (1989), 'Accounting in Developing Countries: A case for localised uniformity', The British Accounting Review, vol. 2, no. 2, pp. 141-158. http://dx.doi.org/10.1016/0890-8389(89)90193-5

Points, R. and Cunningham R. (1998), 'The application of international accounting standards in transitional societies and developing countries. Supplement 1', Advances in International Accounting, pp. 3-16.

Reich, R. (1988), "Corporation and Nation," Atlantic Monthly, May.

Samuels, J. (1990), 'International accounting standards in The Third World: A synthesis of six articles', Research in Third World Accounting, vol. 2, pp. 19-25.

Samuels, J. and Oliga J. (1982), 'Accounting Standards in Developing Countries', International Journal of Accounting Education and Research,, vol. Fall, pp. 69-88.

Saudagaran, S. and Diga J. (1997), 'Accounting Regulation in ASEAN: A choice between the global and regional paradigms of harmonisation', Journal of International Financial Management and Accounting, vol. 8, no. 1, pp. 1-32. http://dx.doi.org/10.1111/1467$\underline{646 X .00015}$

Wallace, R. (1993), 'Development of Accounting Standards for Developing and Newly Industrialised Countries', Research in Third World Accounting, vol. 2, pp. 121-165.

Wallace, R. and Briston R. J. (1993), 'Improving the accounting infrastructure in developing countries', Research in Third World Accounting, vol. 2, pp. 201-224.

Weetman, P. and Gray S. (1991), 'A Comparative Analysis of the Impact of Accounting Principles on Profits: the USA versus the UK, Sweden, and the Netherlands', Accounting and Business Research, vol. 21, no. 84, pp. 363-379. http://dx.doi.org/10.1080/00014788.1991.9729851

Woolley, R. (1998), "International accounting standards and economic growth, an empirical investigation of their relationship in Asia." Working Paper Series, School of Accounting and Law RMIT, Australia.

Yapa, P. (2012), "The Adoption of IFRS in the ASEAN." In conference papers presented at the Singapore Management University, 9 January.

Yapa, P. W. S. (1999), 'Professional accounting environment in Brunei Darussalam', Accounting, Auditing and Accountability Journal, vol. 13, no. 3, pp. 328-339. http://dx.doi.org/10.1108/09513579910277393

Yapa, P. W. S. (2003), 'Accounting Education and Training in ASEAN: The Western Influence and the Experience of Singapore, Malaysia, Indonesia and Brunei Darussalam', Research in Accounting in Emerging Economies, vol. 5, pp. 267-292. http://dx.doi.org/10.1016/S1058-1995(03)05016-3

Yapa, P. W. S. (2005), "The Political Scene and its Impact on the Accounting Profession: the case of Brunei Darussalam." In Critical Perspectives on Accounting Conference, 28-30 April Baruch College, CUNY, USA.

Yapa, P. W. S., Hout C. and Jacobs K. (2007), "The Re-emergence of Accounting Profession in Cambodia." In Fifth Asia Pacific Interdisciplinary Research in Accounting Conference (APIRA), 8-10 July. Auckland, New Zealand. 
AABF J | Volume 9, no. 1, 2015

\section{Appendix A. INTERVIEW PROTOCOL}

\section{Project Title (Stage one):}

The Socio-Economic Impacts of the Adoption of IFRS: a comparative study between the ASEAN countries of Singapore and Malaysia

\section{Interview Questions}

A. What are the impacts of adoption of IFRS on wider stakeholders and on the socio-economy in your country?

1. When your country adopted /harmonised with IFRSs, what benefits do you see for wider society?

2. When your country adopted /harmonised with IFRSs, should financial reports be available on public websites?

3. What economic benefits would you expect as a result of the adoption of IFRSs?

4. What are the major challenges on the adoption of IFRSs in the corporate sector in your country?

5. What is your country's have a daily financial paper? If so, how would you rate its content?

6. Does your have a daily finance report as part of TV news? If so, how would you rate its content?

B. What are the perceived tensions between companies on the potential/adoption of IFRS in your country?

1. When your country adopted /harmonised with IFRSs, what technical and professional staffing issues emerged? For your large companies? For your SME companies?

2. When your country adopted /harmonised with IFRSs, what did you see as the most important standards? What are the least important standards? For your large companies? For your SME companies?

3. Could you explain the major tensions on the adoption of IFRSs for large, medium and small companies?

4. How did the recent financial crisis impact on the adoption of IFRSs in your country?

5. When your country adopted /harmonised with IFRSs, are any aspects of Sharia Law an issue? For your large internationalised companies? For your SME companies?

6. When your country adopted /harmonised with IFRSs, what criticisms have been received from your SME companies? What about SME commitment to financial disclosure?

7. Do you perceive tensions with the use of fair value?

C. How has the accounting profession in your country responded to socio-economic factors arising from the resistance/slow adoption of IFRS.

1. What are your current professional education/training programs on IAS/ IFRSs for members?

2. Has your association conducted any surveys on member issues about IAS/ IFRS?

3. Does your association's journal receive many articles for publication on the adoption/harmonisation of IAS/ IFRS?

4. Does your association's website have material on the adoption/harmonisation of IAS/ IFRS?

5. Do you have data on the numbers of large and SME companies in your country?

6. How would you rate the extent of financial education in your country? Are there any related published statistics you could provide? 
Yapa, Kraal \& Joshi | The adoption of IAS 12 Income Taxes’: Convergence or divergence

\section{Appendix B. INTERVIEW PROTOCOL}

\section{Project Title (Stage two):}

The Socio-Economic Impacts of the Adoption of IFRS: a comparative study between the ASEAN countries of Singapore, Malaysia and Australia

Additional questions to Australian interviewees:

D. Questions about AASB 112 Income Taxes (IAS 12 income Taxes)

1. What is the impact on judgement required by practitioners in relation to Fair Value valuation of an asset, and the comparison to its tax base?

2. What is the impact on judgement required by practitioners in relation to review/discount approaches to tax losses, which were classified as 'Deferred Tax Assets' during the GFC year of 2008/09?

3. What is your view on the difficulties encountered by 'in-house accountants' in determining the tax base of assets/liabilities?

4. Have any recent changes in Australian tax law made calculations under AASB 112 Income Taxes more difficult?

5. What is your view on the benefit to wider stakeholders (shareholders, community etc.) of AASB 112 Income Taxes? 